\title{
Camelina and crambe production - Energy efficiency indices depending on nitrogen fertilizer application
}

\author{
Mariusz Jerzy Stolarski*, Michał Krzyżaniak, Józef Tworkowski, Dariusz Załuski, \\ Jacek Kwiatkowski, Stefan Szczukowski
}

University of Warmia and Mazury in Olsztyn, Faculty of Environmental Management and Agriculture, Department of Plant Breeding and Seed Production, Plac Łódzki 3, 10-724 Olsztyn, Poland

\section{A R T I C L E I N F O}

\section{Keywords:}

Camelina sativa

Crambe abyssinica

Nitrogen fertilization

Energy input

Energy balance

Energy ratio

\begin{abstract}
A B S T R A C T
The energy efficiency indices are not affected by market fluctuations and they are more stable in time and space. The use of mineral fertilizers is a major energy input element in crop production. Therefore, the aim of the study was to determine energy input, energy output, and energy efficiency indices in camelina and crambe biomass (seeds, oil, straw) production depending on rate of mineral nitrogen $(\mathrm{N})$ fertilizer application $(0,60$ and $\left.120 \mathrm{~kg} \mathrm{ha}^{-1} \mathrm{~N}\right)$.

The dry camelina seed yield was significantly differentiated by fertilizer application, while no such relationship was found for crambe. The highest dry seed yield was reached for both species in the warmest 2018 year. The total energy input in crambe production on a plot with no $\mathrm{N}$ fertilizer application was $10.19 \mathrm{GJ} \mathrm{ha}^{-1}$. However, it increased with an increasing $\mathrm{N}$ rate to 13.25 and $16.30 \mathrm{GJ}^{-1}$, for 60 and $120 \mathrm{~kg} \mathrm{ha}^{-1}$, respectively. The energy gain from crambe production was the highest on the plot with no fertilizer application ( $80.9 \mathrm{GJ} \mathrm{ha}^{-1}$ ) and decreased with increasing fertilization rates (by $8 \%$ and $11 \%$, for 60 and $120 \mathrm{~kg} \mathrm{ha}^{-1} \mathrm{~N}$, respectively). Camelina gave the highest energy gain $\left(67.5 \mathrm{GJ} \mathrm{ha}^{-1}\right)$ on the plot with rate $60 \mathrm{~kg} \mathrm{ha}^{-1} \mathrm{~N}$, and an increase in fertilization or its absence decreased this index by $6 \%$ and $3 \%$, respectively. The average energy ratio for crambe seed production (3.9) was significantly higher (by 13\%) compared to the average value for camelina. The application of $\mathrm{N}$ decreased the seed production energy ratio compared to the control plot with $0 \mathrm{~kg} \mathrm{ha}^{-1}$ artificial $\mathrm{N}$ applied, both for camelina and crambe by $13-26 \%$, and by $23-37 \%$, respectively. Further research is needed to verify these findings and to address the issue of economic and environmental production efficiency of these two promising oilseed crops.
\end{abstract}

\section{Introduction}

Camelina (Camelina sativa L. Crantz) and crambe (Crambe abyssinica Hochst ex R.E. Fries) are oilseed crops which have attracted the interest of research centers and industry in many regions around the world (Gesch, 2014; Berti et al., 2016; Zanetti et al., 2017) due to their lower soil-related, nutritional and agrotechnical requirements compared to other oilseed crops, such as rapeseed (Brassica napus L.). Moreover, owing to the beneficial composition of camelina and crambe oils, new methods are sought for converting the oil and the remaining biomass (straw, oilseed cake) of these species into bioproducts and biofuels (Santos et al., 2013; Zanetti et al., 2013; Guan, 2014; Keshavarz-Afshar et al., 2015). Research and development work and pilot projects using camelina and crambe biomass demonstrate that oil obtained from these plants may be used for the production of biodiesel, jet fuel, hydraulic oil, lubricants, polyvinyl ethers and more (Wang et al., 2010; Falasca et al., 2010; Moser, 2010; Kalita et al., 2018; Bustamante et al., 2019; Khusainov et al., 2019). However, energy efficiency assessment for seeds, oil and straw production should be an important factor in the economic justification of their production and further use. Unlike an economic effectiveness assessment, energy efficiency is not affected by market prices fluctuations related to supply and demand or the prices of production means. The energy efficiency indices (e.g. energy ratio, energy intensity) are also more stable in time and space. Therefore, these indices can be used as more reliable measures to compare different biomass production technologies. Obviously, energy input for obtaining a specific biomass type depends on the crop species and the production technology, particularly the agrotechnical practices and means of production (fertilizers, plant protection agents, etc.). Since production technology determines the production equipment and

\footnotetext{
* Corresponding author.

E-mail address: mariusz.stolarski@uwm.edu.pl (M.J. Stolarski).
} 
Table 1

Soil properties in consecutive experimental years.

\begin{tabular}{|c|c|c|c|c|c|c|c|}
\hline Year & Depth (cm) & $\mathrm{N}-\mathrm{NO}_{3}\left(\mathrm{mg} \mathrm{kg}^{-1}\right.$ d.m. $)$ & $\mathrm{N}-\mathrm{NH}_{4}\left(\mathrm{mg} \mathrm{kg}^{-1}\right.$ d.m.) & $\mathrm{pH} \mathrm{KCl}$ & $\mathrm{P}_{2} \mathrm{O}_{5}\left(\mathrm{mg} \mathrm{kg}^{-1}\right.$ soil $)$ & $\mathrm{K}_{2} \mathrm{O}\left(\mathrm{mg} \mathrm{kg}^{-1}\right.$ soil $)$ & $\mathrm{Mg}$ (mg kg${ }^{-1}$ soil) \\
\hline \multirow[t]{2}{*}{2016} & $0-15$ & 18.8 & 1.9 & 6.4 & 110 & 130 & 14 \\
\hline & $15-30$ & 21.4 & 2.1 & & & & \\
\hline \multirow[t]{2}{*}{2017} & $0-15$ & 8.3 & 2.0 & 7.2 & 239 & 215 & 32 \\
\hline & $15-30$ & 6.7 & 1.2 & & & & \\
\hline \multirow[t]{2}{*}{2018} & $0-15$ & 8.9 & 3.5 & 7.0 & 348 & 515 & 79 \\
\hline & $15-30$ & 7.8 & 1.2 & & & & \\
\hline
\end{tabular}

means of production (whose use is related to the energy input), it also affects the amount of energy accumulated in the harvested biomass (energy output) (Alluvione et al., 2011; Budzyński et al., 2015; Jankowski et al., 2015; Stolarski et al., 2016, 2017). The use of mineral fertilizers is a major energy input element in crop biomass production. Therefore, the aim of the study presented in this manuscript was to determine: (i) total energy input, (ii) energy output, and (iii) energy efficiency indices in camelina and crambe biomass (seeds, oil, straw) production depending on mineral $\mathrm{N}$ fertilizer application in the period of three consecutive years of cultivation.

\section{Materials and methods}

\subsection{Field experiment and energy input determination}

The study was based on a three-year field experiment carried out from 2016 to 2018 on land owned by the University of Warmia and Mazury in Olsztyn (N:53 $\left.57^{\prime}, \mathrm{E}: 21^{\circ} 08^{\prime}\right)$. The experiment was conducted on Eutric Cambisols soil formed from loamy sand based on silt. Table 1 presents the content of the main macroelements in the soil in the particular years of the study. The same traditional tillage system was applied in camelina and crambe production. Winter wheat (Triticum aestivum L.) was used each time as a forecrop. A total herbicide containing glyphosate (Roundup $360 \mathrm{SL}$ ) at $5 \mathrm{Lha}^{-1}$ was applied after wheat harvest and after secondary weed appearance on the stubble field. Ploughing at the depth of $20 \mathrm{~cm}$ was conducted before winter. Granulated mineral-organic fertilizer at $300 \mathrm{~kg} \mathrm{ha}^{-1}$ was applied by broadcast in spring over the entire experimental area. The composition of the mineral-organic fertilizer was as follows: $8.0 \% \mathrm{~N}, 11.0 \% \mathrm{P}_{2} \mathrm{O}_{5}, 12.0 \%$ $\mathrm{K}_{2} \mathrm{O}, 8.0 \% \mathrm{CaO}, 7.5 \% \mathrm{SO}_{3}, 0.3 \% \mathrm{MgO}$, including $20 \%$ of organic matter. Harrowing with a heavy harrow was performed twice and seeds were then sown. A two-factorial field experiment in the split-plot design in four replicates was set up in each year, with the species as the first factor (whole plots) and the $\mathrm{N}$ fertilizer dose as the second factor (subplots). Single plot area was $9 \mathrm{~m}^{2}(1.5 \times 6 \mathrm{~m}), 15$ rows with $0.15 \mathrm{~m}$ inter-rows. The whole block for one crop was $108 \mathrm{~m}^{2}(12 \times 6 \mathrm{~m})$. The experiment was conducted in three successive growing seasons. Midas cultivar of camelina and Galactica cultivar of crambe was sown each year at $6 \mathrm{~kg} \mathrm{ha}^{-1}$ and $13 \mathrm{~kg} \mathrm{ha}^{-1}$, respectively. The thousand seed weights for camelina Midas and crambe Galactica were $1.28 \mathrm{~g}$ and $7.35 \mathrm{~g}$, respectively. The following were the sowing/harvest dates for camelina in the successive years: 2016, 2017 and 2018, respectively: 5 April/21 August; 10 April/9 August; 16 April/25 July. The dates for crambe were as follows: 5 April/12 August; 10 April/16 August; 16 April/3 August.

A mineral $\mathrm{N}$ fertilizer was applied by broadcast for each species at three doses in each year of the experiment: 0,60 and $120 \mathrm{~kg} \mathrm{ha}^{-1} \mathrm{~N}$ as ammonium nitrate. The fertilizer at $60 \mathrm{~kg} \mathrm{ha}^{-1} \mathrm{~N}$ was applied once, immediately before the seeds were sown. A double dose of $120 \mathrm{~kg} \mathrm{ha}^{-1}$ $\mathrm{N}$ was applied in two equal rates of $60 \mathrm{~kg} \mathrm{ha}^{-1} \mathrm{~N}$ : before the seeds were sown and immediately before the main stem elongation. Glyphosate (Roundup $360 \mathrm{SL}$ ) was applied at $4 \mathrm{~L} \mathrm{ha}^{-1}$ two weeks before planned harvest to ensure uniform ripening of the plants. For the energy efficiency analyses, it was assumed that the plants were harvested in one step with a New Holland TC5070 combine harvester. It was also assumed that the straw was pressed in round bales after it dried naturally in swathes. The seeds and straw were transported to the farmstead.

The total energy input ( $\mathrm{GJ} \mathrm{ha}^{-1}$ ) for camelina and crambe production was determined as the total input of four energy sources: (i) direct energy carriers - diesel fuel; (ii) exploitation of fixed assets - tractors, machines, equipment; (iii) consumption of materials - mineral fertilizers, agrochemicals, seeds; and (iv) human labor. The total energy input in biomass production of the two species under study was calculated based on the total material consumption and the energy intensity of their production. Literature data (Neeft et al., 2011; Szeptycki and Wójcicki, 2003) provided the following energy conversion coefficients for calculations: diesel fuel (43.1 $\mathrm{MJ} \mathrm{kg}^{-1}$ ), $\mathrm{N}$ fertilizers (48.99 $\mathrm{MJ} \mathrm{kg}^{-1}$ $\mathrm{N}$ ), mineral-organic fertilizer (15.23 $\mathrm{MJ} \mathrm{kg}^{-1}$ ), pesticides $\left(268.4 \mathrm{MJ} \mathrm{kg}^{-1}\right.$ of active substance), seeds for sowing $\left(12 \mathrm{MJ} \mathrm{kg}^{-1}\right)$, tractors (125 MJ $\left.\mathrm{kg}^{-1}\right)$, machines $\left(110 \mathrm{MJ} \mathrm{kg}^{-1}\right)$ and human labor $\left(60 \mathrm{MJ} \mathrm{h}^{-1}\right)$. The technical details of the machines, tractors and tools used in the analysis of camelina and crambe production technology are presented in Stolarski et al. (2018).

\subsection{Determination yield of biomass, yield energy value and energy efficiency indices}

Camelina and crambe were harvested in the successive years of the experiment. The biomass was subsequently weighed to determine the seed and straw yield from the $9 \mathrm{~m}^{2}$ plots; it was then calculated per $1 \mathrm{ha}$. Samples of seeds and straw for laboratory analyses were collected during the harvest in each year. The analyses included oil content determination (according to PN-EN ISO 734: 2016-03 standard) in dry seeds and it was used to calculate the oil yield per unit area $\left(\mathrm{Mg} \mathrm{ha}^{-1}\right)$. The calculated parameters also included the moisture content (according to PN-EN 18134-1: 2015-11 standard) and higher heating value, which were used to calculate the lower heating value (LHV) (according to the PN-EN ISO 18125: 2017 standard) for seeds and straw of the species. The fresh matter (f.m.) seed and straw yield $\left(\mathrm{Mg} \mathrm{ha}^{-1}\right)$ and their LHV ( $\mathrm{GJ} \mathrm{Mg}^{-1}$ ) were used to calculate the yield energy value of camelina and crambe (GJ ha $\left.{ }^{-1}\right)$.

The accumulated energy gain $\left(\mathrm{GJ} \mathrm{ha}^{-1}\right)$ was then calculated as the difference between the camelina or crambe biomass yield energy value and the total input for their production. Another index was the energy intensity, which was the energy consumed per $1 \mathrm{Mg}$ of seed or straw or oil (GJ Mg ${ }^{-1}$ seeds, straw or oil) and was calculated as the ratio of total energy input to the yield of seeds, straw or oil. The last index was the energy efficiency ratio of seeds and straw production, calculated as the ratio of the yield energy value (energy output) to energy input for its production.

\subsection{Statistical analysis}

The characteristics were analyzed in accordance with the variance analysis model for a three-year series of split-plot design experiments at a level of significance of $\alpha=0.05$. This model contains three errors: Error 1 was the basis for assessment of difference significance for a series of years (Y); Error 2 tested the significance of differences between the species (factor A) and interactions with the years of study (YA) and Error 3 was the basis for assessment of the remaining effects, i.e. 


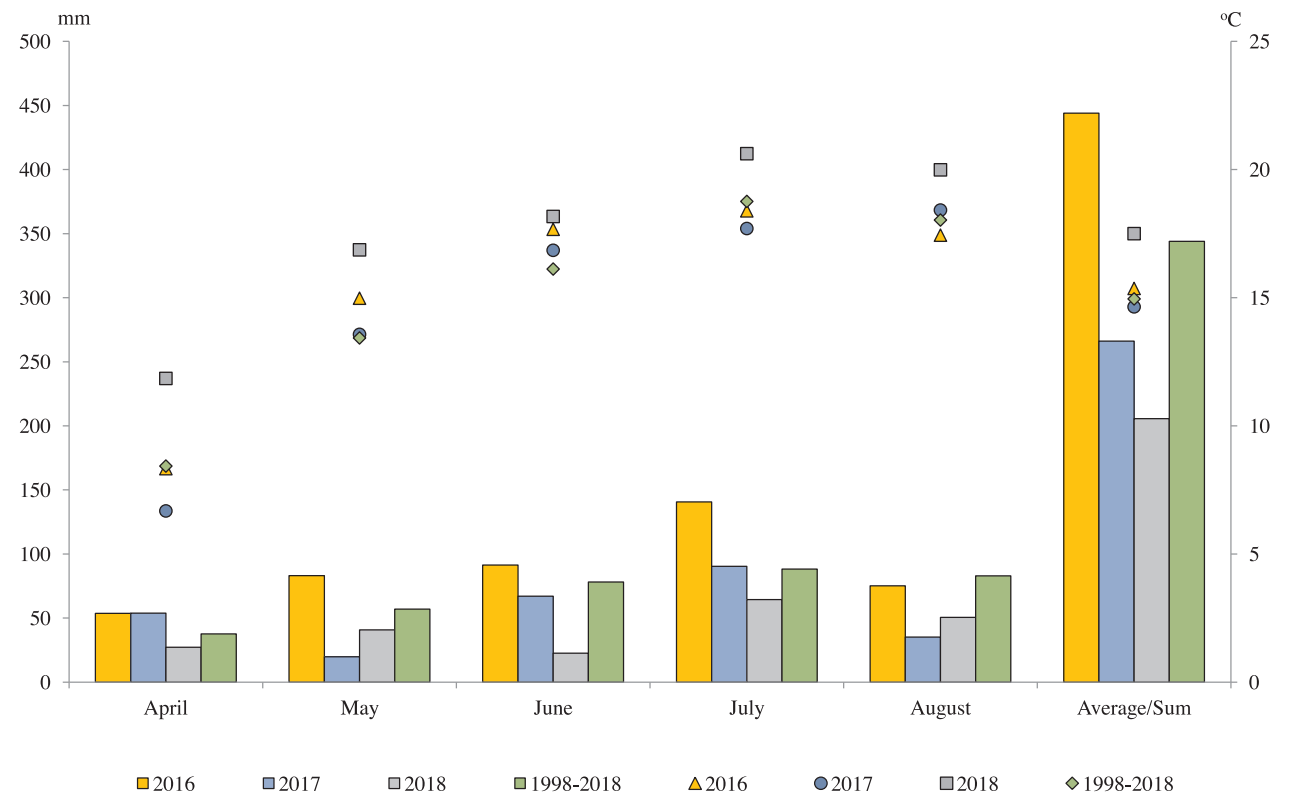

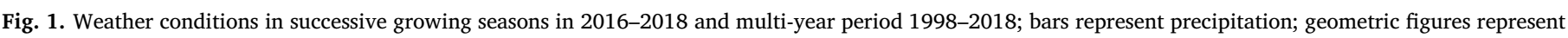
air temperatures.

fertilization (factor B) and interactions of factors $A B, Y B$ and YAB. Tukey's test was then used to assess the significance of differences between the means with $\mathrm{P}<0.05$. All statistical analyses were performed with STATISTICA 13.3 software.

\section{Results and discussion}

\subsection{Weather conditions and biomass yield}

The weather conditions in April-August and throughout the growing season in the successive experiment years and in the multi-year period are shown in Fig. 1. The average temperature during the 2016 growing season was $0.4{ }^{\circ} \mathrm{C}$ higher and the total rainfall was $29 \%$ higher compared to the multi-year period. The 2017 growing season was the coldest with the average temperature $0.3^{\circ} \mathrm{C}$ lower compared to the multi-year period. However, the 2018 growing season was the warmest and the rainfall level was the lowest. The average temperature was $2.5{ }^{\circ} \mathrm{C}$ higher and the rainfall was $40 \%$ lower compared to the multiyear period (1998-2018).

The seed yield was significantly differentiated by the species $(P=0.004)$ and the fertilization rates $(P=0.011)$ as well as by the combination of these factors $(P=0.018)$ and by the years $(P<0.001)$. The weather conditions during the individual experiment years thus had a significant effect on the plant yield (Tables $2 \mathrm{a}$ and $2 \mathrm{~b}$ ). The highest seed yields for crambe and camelina in north-eastern Poland were obtained in 2018 (the warmest year with the lowest rainfall) and were on average 3.07 and $2.21 \mathrm{Mg} \mathrm{ha}^{-1}$ f.m., respectively (Table 3). This fact could partially be explained by the distribution of precipitation which was favorable to plant growth and development in the vegetation period of 2018. Moreover, such low rainfall $(206 \mathrm{~mm})$ in that period, under the climatic conditions of north-eastern Poland was sufficient for the experimental plant species. Soil infiltration with water was also at a good level and the plants could use ground waters accumulated in the winter. In general, crambe gave a higher seed yield than camelina, particularly in the warmest year of the experiment. Fertilization of camelina with $\mathrm{N}$ at 60 and $120 \mathrm{~kg} \mathrm{ha}^{-1}$ was found to increase the yield compared to the control, by $13 \%$ and $20 \%$, respectively. However, the crambe seed yield was not found to respond positively to $\mathrm{N}$ fertilization. It should be added that the weak response to camelina seed increase and practically no response of crambe to the application of $\mathrm{N}$ fertilizer could have resulted from the well-maintained soil (cultivated in compliance with the principles of agricultural good practice and maintaining adequate crop rotation) and its abundance left after the forecrop and the mineral-organic fertilizer applied before sowing. Moreover, crambe seed yield (1.26-3.19 $\mathrm{Mg} \mathrm{ha}^{-1}$ f.m.) was found to be highly variable during the experiment. The high variability of crambe seed yield in the climate conditions of north-eastern Poland was confirmed in an earlier study (Stolarski et al., 2018). The same relationships (as with the seed yield) were observed with the straw yield, which was significantly higher for crambe, $2.56 \mathrm{Mg} \mathrm{ha}^{-1}$ f.m., on average (Table 3). Moreover, it was significantly higher in 2018 (3.27 Mg ha ${ }^{-1}$ f.m. on average) and was nearly $4 \mathrm{Mg} \mathrm{ha}^{-1} \mathrm{f} . \mathrm{m}$. on the control plot with $0 \mathrm{~kg} \mathrm{ha}^{-1}$ artificial $\mathrm{N}$ applied. Fertilizer application did not affect the straw yield in either of the species under study. However, the camelina straw yield averaged $2.19 \mathrm{Mg} \mathrm{ha}^{-1}$ f.m. and it ranged from 1.47 to 3.03 $\mathrm{Mg} \mathrm{ha}^{-1}$ f.m.

The mean crambe yield was found to be significantly higher (1.91 Mg ha ${ }^{-1}$ d.m.) compared to the camelina seed yield (1.59 $\mathrm{Mg} \mathrm{ha}^{-1}$ d.m.) (Table S1). The dry camelina seed yield was significantly differentiated by fertilizer application, while no such relationship was found for crambe. Moreover, the highest dry seed yield was reached for both species in the final year (2018), which was the warmest. The mean camelina and crambe yields in an earlier large-scale experiment were similar (1.1 $\mathrm{Mg} \mathrm{ha}^{-1}$ d.m.) (Stolarski et al., 2018). However, the yields were also significantly differentiated by the species and the study years. The camelina seed yield in $2017\left(1.26 \mathrm{Mg} \mathrm{ha}^{-1} \mathrm{~d}\right.$.m.) was significantly higher than the crambe seed yield $\left(0.86 \mathrm{Mg} \mathrm{ha}^{-1} \mathrm{~d}\right.$.m.). A very high diversity of the crambe seed yield in experiments conducted in Poland was observed in previous studies (Jankowski and Budzyński, 2003; Kulig et al., 2004; Stolarski et al., 2013). The average crambe seed yield in those studies was found to be approx. $1.5 \mathrm{Mg} \mathrm{ha}^{-1}$ and ranged from 0.3 to $3.0 \mathrm{Mg} \mathrm{ha}{ }^{-1}$. Meanwhile, the crambe seed yield obtained in another study in a warmer climate of Italy was more stable and ranged from 2.2 to $3.3 \mathrm{Mg} \mathrm{ha}^{-1} \mathrm{~d}$.m. depending on the variety and the study year (Zanetti et al., 2016). Furthermore, studies by other authors (Berti et al., 2011, 2016; Schillinger et al., 2012; Zanetti et al., 2017) reported that camelina seed yield to be the most stable and was approx. $1.5 \mathrm{Mg}$ ha $^{-1}$ d.m., reaching $3 \mathrm{Mg} \mathrm{ha}^{-1} \mathrm{~d}$.m. under optimum conditions (which could not be obtained in this study). However, the mean dry straw yields of crambe and camelina in the current study were similar, $2.2 \mathrm{Mg}$ 
$\mathrm{ha}^{-1}$ d.m. and $1.9 \mathrm{Mg} \mathrm{ha}^{-1}$ d.m., respectively (Table S1). Although the yields varied in subsequent study years, with the significantly highest for crambe in 2018 and for crambe and camelina in 2016, and the significantly lowest for both species in 2017. Similar variability in camelina and crambe straw yield was found in earlier field studies (Stolarski et al., 2013, 2018).

The oil yield in this experiment was mainly significantly differentiated by the $\mathrm{N}$ fertilization rate and by the year of study (Tables $2 \mathrm{a}$ and $2 \mathrm{~b}$ ). The average oil yield was similar for both species (approx. $0.6 \mathrm{Mg} \mathrm{ha}^{-1}$ ) and it was slightly higher for camelina (Table 3). The highest camelina oil yield was obtained when the higher $\mathrm{N}$ fertilization rate of $120 \mathrm{~kg} \mathrm{ha}^{-1} \mathrm{~N}$, was applied $\left(0.69 \mathrm{Mg} \mathrm{ha}^{-1}\right)$. The lowest camelina oil yield $\left(0.57 \mathrm{Mg} \mathrm{ha}^{-1}\right)$ was obtained on the control plot with $0 \mathrm{~kg} \mathrm{ha}^{-1}$ artificial $\mathrm{N}$ applied. The crambe oil yield throughout the experiment ranged from $0.36-0.92$ with no fertilization in 2017 and 2018, respectively. This indicates the very high variability of crambe yield in north-eastern Poland.

\subsection{Lower heating value and yield energy value}

Lower heating value was significantly differentiated $(P<0.001)$ by all of the main factors (species, fertilization, year) and by the interactions between them (Tables $2 \mathrm{a}$ and $2 \mathrm{~b}$ ). In general, the lower heating value for the seeds was higher than for the straw (Table 4). It was found in the inter-species comparison that the average lower heating values for both camelina seeds $\left(25.0 \mathrm{MJ} \mathrm{kg}^{-1}\right)$ and straw $\left(16.1 \mathrm{MJ} \mathrm{kg}^{-1}\right)$ were approx. 5\% higher compared to these values for crambe. A lower heating value was higher for camelina seeds and straw obtained from the control plot with $0 \mathrm{~kg} \mathrm{ha}^{-1}$ artificial $\mathrm{N}$ applied. It was the opposite for crambe. The lower heating value determined in other studies was also higher for seeds $\left(19.9-24.9 \mathrm{MJ} \mathrm{kg}^{-1}\right)$ than for straw (15.5-16.6 $\mathrm{MJ} \mathrm{kg}^{-1}$ ) of both species (Stolarski et al., 2018).

The seed energy value was significantly differentiated by the main factors and by the interactions between them. The straw energy value and the total energy value were significantly differentiated by the study years (Tables 2a and 2b). The energy value of crambe seeds (average $50 \mathrm{GJ} \mathrm{ha}^{-1}$ ) was significantly higher than the energy value of camelina seeds (Table 5). Mineral fertilization increased the seed energy value significantly only in camelina. The highest seed yield energy value was for both species in 2018. The straw yield energy value was significantly differentiated only by the study year. For the straw and seed energy value, a higher average energy output was obtained from total biomass of crambe: $89.1 \mathrm{GJ} \mathrm{ha}^{-1}$. The highest energy output (123.5 GJ ha ${ }^{-1}$ ) from the cultivation of this species was obtained in 2018. Camelina also had the highest energy output in the same year and it was lower by approx. $32 \mathrm{GJ} \mathrm{ha}^{-1}$ than the highest value for crambe. Nitrogen fertilizer applied at the lower rate of $60 \mathrm{~kg} \mathrm{ha}^{-1}$ had a positive effect on the total energy output only for camelina. Doubling the $\mathrm{N}$ rate did not increase the energy output. However, it was the opposite with crambe the highest energy output was obtained on the control plot with $0 \mathrm{~kg}$ $\mathrm{ha}^{-1}$ artificial $\mathrm{N}$ applied.

In another three-year large-scale study, higher energy output was obtained from the total biomass of camelina; the highest energy output $\left(79.5 \mathrm{GJ} \mathrm{ha}^{-1}\right.$ ) from cultivation of this species was obtained in 2017. Furthermore, crambe gave the highest energy output in 2016, and it was approx. $6 \mathrm{GJ}$ ha $^{-1}$ lower than the highest value for camelina (Stolarski et al., 2018). Literature reports also confirm that the energy value of camelina and crambe biomass was highly differentiated by the species, site-related factors and by the production technology. For example, the energy value of camelina obtained in studies conducted in Poland (81.4 GJ ha ${ }^{-1}$ ) was also higher than that obtained from crambe (62.3 GJ ha ${ }^{-1}$ ) (Jankowski and Budzyński, 2004). However, the total energy value was lower $\left(72.0 \mathrm{GJ} \mathrm{ha}^{-1}\right.$ ) in a different study (Bielski et al., 2014). Furthermore, the average energy value of camelina seeds determined in a different study was $24.0 \mathrm{GJ} \mathrm{ha}^{-1}$ (range 11.7-31.7 GJ $\mathrm{ha}^{-1}$ ) (Keshavarz-Afshar and Chen, 2015). It was also shown in a 
Table 2b

Variance analysis for a three-year series in a split-plot design (part 2).

\begin{tabular}{|c|c|c|c|c|c|c|c|c|c|c|c|c|c|c|c|}
\hline \multirow[t]{3}{*}{ Source of variation } & \multirow[t]{3}{*}{ df } & \multicolumn{2}{|c|}{ Energy gain $\left(\mathrm{GJ} \mathrm{ha}^{-1}\right)$} & \multicolumn{6}{|c|}{ Energy intensity (GJ $\mathrm{Mg}^{-1}$ ) } & \multicolumn{6}{|c|}{ Energy efficiency ratio } \\
\hline & & \multirow[b]{2}{*}{$\mathrm{F}$} & \multirow[b]{2}{*}{$\mathrm{P}$} & \multicolumn{2}{|l|}{ Seed } & \multicolumn{2}{|l|}{ Straw } & \multicolumn{2}{|l|}{ Oil } & \multicolumn{2}{|l|}{ Seed } & \multicolumn{2}{|c|}{ Straw } & \multicolumn{2}{|l|}{ Total } \\
\hline & & & & $\mathrm{F}$ & $\mathrm{P}$ & $\mathrm{F}$ & $\mathrm{P}$ & $\mathrm{F}$ & $\mathrm{P}$ & $\mathrm{F}$ & $\mathrm{P}$ & $\mathrm{F}$ & $\mathrm{P}$ & $\mathrm{F}$ & $\mathrm{P}$ \\
\hline Year (Y) & 2 & 51.7 & $<0.001$ & 86.8 & $<0.001$ & 54.2 & $<0.001$ & 105 & $<0.001$ & 86.7 & $<0.001$ & 24.6 & $<0.001$ & 44.6 & $<0.001$ \\
\hline Error 1 & 9 & & & & & & & & & & & & & & \\
\hline Species (A) & 1 & 5.3 & 0.047 & 4.0 & 0.078 & 4.0 & 0.076 & 5 & 0.058 & 7.6 & 0.022 & 2.0 & 0.195 & 4.6 & 0.061 \\
\hline YA & 2 & 5.4 & 0.028 & 1.7 & 0.244 & 2.4 & 0.142 & 9 & 0.008 & 5.2 & 0.031 & 4.5 & 0.044 & 5.2 & 0.031 \\
\hline Error 2 & 9 & & & & & & & & & & & & & & \\
\hline Fertilization (B) & 2 & 1.2 & 0.318 & 43.5 & $<0.001$ & 21.1 & $<0.001$ & 40 & $<0.001$ & 84.4 & $<0.001$ & 22.6 & $<0.001$ & 44.9 & $<0.001$ \\
\hline YB & 4 & 1.3 & 0.295 & 0.7 & 0.577 & 0.6 & 0.674 & 1 & 0.626 & 9.6 & $<0.001$ & 2.2 & 0.090 & 4.4 & 0.006 \\
\hline $\mathrm{AB}$ & 2 & 0.8 & 0.465 & 2.4 & 0.103 & 0.7 & 0.522 & 4 & 0.023 & 7.3 & 0.002 & 0.3 & 0.772 & 1.4 & 0.254 \\
\hline YAB & 4 & 1.6 & 0.204 & 2.1 & 0.105 & 0.3 & 0.851 & 2 & 0.110 & 1.8 & 0.149 & 2.0 & 0.113 & 2.3 & 0.075 \\
\hline Error 3 & 36 & & & & & & & & & & & & & & \\
\hline
\end{tabular}

different study in the USA that the average energy value of camelina seeds was low, only 19.0 GJ ha ${ }^{-1}$ (Keshavarz-Afshar et al., 2015). However, it increased with $\mathrm{N}$ fertilization rate from 0 to $90 \mathrm{~kg} \mathrm{~N} \mathrm{ha}^{-1}$ and it was higher for conventional tillage than for the no-tillage system and reached $25 \mathrm{GJ} \mathrm{ha}^{-1}$. In the current study, a higher energy value of camelina seeds (34-59 GJ ha ${ }^{-1}$ ) was obtained with increasing rates of $\mathrm{N}$ fertilization throughout the experiment.

\subsection{Energy inputs}

Since the same cultivation and harvest technology was applied in the production of camelina and crambe throughout the experiment, the average energy input for each stage of the production process was the same, except for sowing, in which it was $0.084 \mathrm{GJ} \mathrm{ha}^{-1}$ higher for crambe due to the higher weight for the sown seeds. However, they were differentiated for both species because of no $\mathrm{N}$ fertilization (or different rates). The total energy input in crambe production with no $\mathrm{N}$ fertilization was $10.19 \mathrm{GJ} \mathrm{ha}^{-1}$ (Fig. 2). However, it increased with increasing $\mathrm{N}$ rate to $13.25 \mathrm{GJ} \mathrm{ha}^{-1}$ and $16.30 \mathrm{GJ} \mathrm{ha}^{-1}$, for 60 and $120 \mathrm{~kg}$ $\mathrm{ha}^{-1} \mathrm{~N}$, respectively. Similar relationships were observed for energy input in camelina production, although it was $0.084 \mathrm{GJ} \mathrm{ha}^{-1}$ lower in each production variant due to the lower weight of the seeds sown. The energy input in crambe and camelina production was $14 \mathrm{GJ} \mathrm{ha}^{-1}$ in an earlier study, when $\mathrm{N}$ fertilization at $100 \mathrm{~kg} \mathrm{ha}^{-1}$ was applied (Stolarski et al., 2018). In another study carried out in Poland, the energy input for camelina production amounted to $12.8 \mathrm{GJ} \mathrm{ha}^{-1}$ and it was lower than for white mustard (Sinapis alba L.), spring and winter rapeseed (by 3.1; 42.2 and 94.5\%, respectively) (Bielski et al., 2014). Similar or slightly lower energy input (11.2-14.8 GJ ha ${ }^{-1}$ ) in spring oil crop production compared to that determined in the current study for camelina and crambe was found in another study (Jankowski et al., 2015). In contrast, the total energy input was much higher for winter rapeseed and exceeded $26 \mathrm{GJ} \mathrm{ha}^{-1}$. Very low energy input for camelina production $\left(1.42 \mathrm{GJ} \mathrm{ha}^{-1}\right)$ was demonstrated when the species was grown with no $\mathrm{N}$ fertilization (Keshavarz-Afshar et al., 2015). In variants with $\mathrm{N}$ fertilization of 45 and $90 \mathrm{~kg} \mathrm{ha}^{-1} \mathrm{~N}$, the total energy input increased by $186 \%$ and $365 \%$, respectively. However, it was still several times lower than in this our experiment.

The highest energy input was related to mineral $\mathrm{N}$ and mineral-organic fertilization and the energy streams in camelina and crambe production were thus dominated by material consumption, including mainly fertilizers. The mineral-organic fertilizer accounted for $45.2-44.8 \%$ of the total energy input in camelina and crambe production, respectively, even on the control plot with $0 \mathrm{~kg} \mathrm{ha}^{-1}$ artificial $\mathrm{N}$ applied (Fig. 3). This was followed in variants with no $\mathrm{N}$ fertilization by input related to diesel fuel consumption, which accounted for ca. $31 \%$, on average. Furthermore, the energy input related to use of tractors and machines accounted for ca. 10\%, and human labor accounted for $4 \%$. Obviously, an increase in $\mathrm{N}$ fertilization resulted in an increase in the input related to material consumption. At the highest rate of $120 \mathrm{~kg}$ $\mathrm{ha}^{-1}, \mathrm{~N}$ fertilization became the dominant energy stream in the production of both species (36\%). Furthermore, all of the materials

Table 3

The fresh matter (f.m.) seed, straw and oil yield for the species depending on nitrogen fertilizer application in the three successive years of the experiment.

\begin{tabular}{|c|c|c|c|c|c|c|}
\hline \multirow[t]{2}{*}{ Year (nitrogen fertilizer rate $\left(\mathrm{kg} \mathrm{ha}^{-1}\right)$} & \multicolumn{2}{|c|}{ Seed yield ( $\mathrm{Mg} \mathrm{ha}^{-1}$ f.m.) } & \multicolumn{2}{|c|}{ Straw yield ( $\mathrm{Mg} \mathrm{ha}^{-1}$ f.m.) } & \multicolumn{2}{|c|}{ Oil yield $\left(\mathrm{Mg} \mathrm{ha}^{-1}\right)$} \\
\hline & Camelina & Crambe & Camelina & Crambe & Camelina & Crambe \\
\hline $2016(0)$ & $1.54 \pm 0.22$ & $1.87 \pm 0.43$ & $3.14 \pm 0.73$ & $2.93 \pm 1.12$ & $0.48 \pm 0.07$ & $0.55 \pm 0.13$ \\
\hline $2016(60)$ & $1.73 \pm 0.34$ & $1.93 \pm 0.08$ & $3.03 \pm 0.46$ & $2.94 \pm 0.38$ & $0.57 \pm 0.11$ & $0.58 \pm 0.03$ \\
\hline $2016(120)$ & $1.76 \pm 0.27$ & $1.89 \pm 0.17$ & $2.49 \pm 0.49$ & $2.88 \pm 0.32$ & $0.57 \pm 0.09$ & $0.58 \pm 0.05$ \\
\hline $2017(0)$ & $1.13 \pm 0.25$ & $1.26 \pm 0.04$ & $1.48 \pm 0.47$ & $1.31 \pm 0.28$ & $0.44 \pm 0.10$ & $0.36 \pm 0.01$ \\
\hline $2017(60)$ & $1.37 \pm 0.16$ & $1.46 \pm 0.25$ & $1.49 \pm 0.35$ & $1.69 \pm 0.57$ & $0.54 \pm 0.06$ & $0.41 \pm 0.07$ \\
\hline $2017(120)$ & $1.57 \pm 0.07$ & $1.35 \pm 0.26$ & $1.47 \pm 0.38$ & $1.54 \pm 0.26$ & $0.61 \pm 0.03$ & $0.39 \pm 0.08$ \\
\hline $2018(0)$ & $2.04 \pm 0.31$ & $3.19 \pm 0.32$ & $2.11 \pm 0.53$ & $3.91 \pm 1.63$ & $0.79 \pm 0.12$ & $0.92 \pm 0.09$ \\
\hline $2018(60)$ & $2.25 \pm 0.39$ & $2.93 \pm 0.10$ & $2.25 \pm 0.58$ & $2.82 \pm 0.21$ & $0.85 \pm 0.15$ & $0.83 \pm 0.03$ \\
\hline 2018 (120) & $2.33 \pm 0.33$ & $3.11 \pm 0.14$ & $2.24 \pm 0.28$ & $3.07 \pm 0.36$ & $0.88 \pm 0.12$ & $0.87 \pm 0.04$ \\
\hline (0) & $1.57 \pm 0.46 c$ & $2.10 \pm 0.89 a$ & $2.24 \pm 0.89$ & $2.72 \pm 1.53$ & $0.57 \pm 0.18 b$ & $0.61 \pm 0.26 a b$ \\
\hline$(60)$ & $1.78 \pm 0.47 b$ & $2.10 \pm 0.66 a$ & $2.26 \pm 0.78$ & $2.48 \pm 0.70$ & $0.65 \pm 0.18 a b$ & $0.61 \pm 0.18 a b$ \\
\hline (120) & $1.89 \pm 0.41 a b$ & $2.12 \pm 0.79 a$ & $2.07 \pm 0.58$ & $2.49 \pm 0.76$ & $0.69 \pm 0.17 a$ & $0.61 \pm 0.21 a b$ \\
\hline 2016 & $1.68 \pm 0.27 \mathrm{c}$ & $1.89 \pm 0.25 \mathrm{c}$ & $2.89 \pm 0.60 \mathrm{ab}$ & $2.92 \pm 0.64 \mathrm{ab}$ & $0.54 \pm 0.09$ & $0.57 \pm 0.07$ \\
\hline 2017 & $1.35 \pm 0.25 \mathrm{~d}$ & $1.36 \pm 0.21 \mathrm{~d}$ & $1.48 \pm 0.37 \mathrm{c}$ & $1.51 \pm 0.39 \mathrm{c}$ & $0.53 \pm 0.09$ & $0.39 \pm 0.06$ \\
\hline 2018 & $2.21 \pm 0.33 \mathbf{b}$ & $3.07 \pm 0.22 \mathrm{a}$ & $2.20 \pm 0.44 \mathbf{b}$ & $3.27 \pm 1.00 \mathrm{a}$ & $0.84 \pm 0.12$ & $0.87 \pm 0.07$ \\
\hline Mean & $1.75 \pm 0.45 b$ & $2.11 \pm 0.76 \mathrm{a}$ & $2.19 \pm 0.75 b$ & $2.56 \pm 1.04 \mathrm{a}$ & $0.64 \pm 0.18$ & $0.61 \pm 0.21$ \\
\hline
\end{tabular}

Mean \pm standard deviation; $\mathrm{a}, \mathrm{b}-$ homogeneous groups for species effect; $\mathbf{a}, \mathbf{b}, \ldots, \mathbf{d}$ - homogeneous groups for interactions year and species; $a, a b, b-$ homogeneous groups for interactions nitrogen fertilizer rate and species. No letter denotes statistical insignificance of the main effect or interaction. 
Table 4

Lower heating values of seeds and straw $\left(\mathrm{GJ} \mathrm{Mg}^{-1}\right.$ ) for the species depending on nitrogen fertilizer application in three successive study years.

\begin{tabular}{|c|c|c|c|c|}
\hline \multirow[t]{2}{*}{ Year (nitrogen fertilizer rate $\left(\mathrm{kg} \mathrm{ha}^{-1}\right)$} & \multicolumn{2}{|l|}{ Seeds } & \multicolumn{2}{|l|}{ Straw } \\
\hline & Camelina & Crambe & Camelina & Crambe \\
\hline $2016(0)$ & $24.5 \pm 0.006 f$ & $23.5 \pm 0.040 k$ & $15.9 \pm 0.108 d$ & $14.7 \pm 0.064 i$ \\
\hline $2016(60)$ & $24.4 \pm 0.020 \mathrm{~g}$ & $23.5 \pm 0.041 k$ & $15.7 \pm 0.079 e$ & $15.0 \pm 0.091 h$ \\
\hline 2016 (120) & $24.3 \pm 0.001 \boldsymbol{h}$ & $23.5 \pm 0.054 k$ & $15.4 \pm 0.110 \mathrm{~g}$ & $14.8 \pm 0.099 h i$ \\
\hline $2017(0)$ & $25.2 \pm 0.021 c$ & $23.7 \pm 0.047 i$ & $16.2 \pm 0.033 c$ & $15.4 \pm 0.054 f g$ \\
\hline $2017(60)$ & $25.1 \pm 0.024 d$ & $24.0 \pm 0.039 h$ & $15.9 \pm 0.039 \mathrm{de}$ & $15.4 \pm 0.053 g$ \\
\hline 2017 (120) & $25.0 \pm 0.025 e$ & $24.4 \pm 0.024 g$ & $15.8 \pm 0.041 \mathrm{de}$ & $15.5 \pm 0.078 f g$ \\
\hline $2018(0)$ & $25.4 \pm 0.012 a$ & $23.6 \pm 0.059 j$ & $16.6 \pm 0.053 a$ & $15.6 \pm 0.050 f$ \\
\hline $2018(60)$ & $25.3 \pm 0.007 b$ & $23.6 \pm 0.014 \boldsymbol{j}$ & $16.5 \pm 0.042 a b$ & $15.4 \pm 0.047 f g$ \\
\hline 2018 (120) & $25.3 \pm 0.012 b$ & $23.6 \pm 0.002 j$ & $16.4 \pm 0.047 b$ & $15.8 \pm 0.033 e$ \\
\hline (0) & $25.1 \pm 0.396 a$ & $23.6 \pm 0.089 f$ & $16.3 \pm 0.306 a$ & $15.2 \pm 0.411 e$ \\
\hline$(60)$ & $25.0 \pm 0.401 b$ & $23.7 \pm 0.233 e$ & $16.0 \pm 0.375 b$ & $15.3 \pm 0.214 d e$ \\
\hline (120) & $24.9 \pm 0.428 c$ & $23.8 \pm 0.400 d$ & $15.9 \pm 0.446 c$ & $15.4 \pm 0.405 d$ \\
\hline 2016 & $24.4 \pm 0.080 \mathrm{c}$ & $23.5 \pm 0.042 \mathbf{f}$ & $15.7 \pm 0.260 \mathrm{c}$ & $14.9 \pm 0.415 \mathrm{e}$ \\
\hline 2017 & $25.1 \pm 0.068 \mathbf{b}$ & $24.0 \pm 0.292 \mathrm{~d}$ & $16.0 \pm 0.167 b$ & $15.4 \pm 0.061 \mathrm{~d}$ \\
\hline 2018 & $25.4 \pm 0.049 \mathbf{a}$ & $23.6 \pm 0.035 \mathrm{e}$ & $16.5 \pm 0.106 \mathbf{a}$ & $15.6 \pm 0.142 \mathrm{c}$ \\
\hline Mean & $25.0 \pm 0.402 \mathrm{a}$ & $23.7 \pm 0.280 \mathrm{~b}$ & $16.1 \pm 0.402 \mathrm{a}$ & $15.3 \pm 0.348 b$ \\
\hline
\end{tabular}

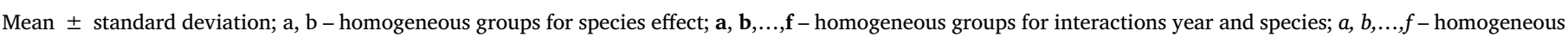
groups for interactions nitrogen fertilizer rate and species; $\boldsymbol{a}, \boldsymbol{b}, \ldots \boldsymbol{k}$ - homogeneous groups for interactions year and nitrogen fertilizer rate and species.

combined accounted for over $70 \%$ of all the energy streams. Fuels accounted for approx. 20\%, the use of tractors and machines for nearly $7 \%$, and human labor for $2.6 \%$. A similar energy stream structure was also identified in other studies in which $\mathrm{N}$ fertilizer was applied (Stolarski et al., 2018; Keshavarz-Afshar et al., 2015).

\subsection{Energy gain}

The energy gain was significantly differentiated only by the species and study years and by their interactions; no significant effect of $\mathrm{N}$ fertilizer application on this characteristic was identified (Tables 2a and $2 \mathrm{~b})$. The average energy gain from the production of crambe $(75.8 \mathrm{GJ}$ $\mathrm{ha}^{-1}$ ) was $14 \%$ higher compared to the average value obtained from camelina (Table 5). The highest energy gain during the study was obtained from crambe in $2018\left(110.2 \mathrm{GJ} \mathrm{ha}^{-1}\right)$ and it was lower in 2016 and 2017 (by $32 \%$ and $61 \%$, respectively). The energy gain from camelina production in the current experiment was $28-60 \%$ lower compared to the highest gain obtained from crambe production. Due to the higher input for $\mathrm{N}$ fertilization, the energy gain from crambe production was the highest on the plot with no fertilization $\left(80.9 \mathrm{GJ} \mathrm{ha}^{-1}\right)$ and decreased with increasing fertilization rates (by $8 \%$ and $11 \%$, for 60 and $120 \mathrm{~kg} \mathrm{ha}^{-1} \mathrm{~N}$, respectively). Camelina gave the highest energy gain $\left(67.5 \mathrm{GJ} \mathrm{ha}^{-1}\right)$ on the plot with a lower $\mathrm{N}$ fertilization rate, and an increase in fertilization or its absence decreased this index by $6 \%$ and $3 \%$, respectively. Large (2-3-fold) differences in energy gain were determined throughout the experiment for both crambe and camelina (ranging from 40 to $126 \mathrm{GJ} \mathrm{ha}^{-1}$ and $42-81 \mathrm{GJ} \mathrm{ha}^{-1}$, respectively). In a large-scale study, the average energy gain from three-year camelina production was $4.9 \%$ higher compared to the average value for crambe (Stolarski et al., 2018). The highest energy gain in that study was obtained from camelina in $2017\left(64.4 \mathrm{GJ} \mathrm{ha}^{-1}\right)$. In contrast, it was lower in 2016 and 2015 (by 16\% and 21\%, respectively). Furthermore, the energy gain from crambe production was $9-22 \%$ lower compared to the highest value obtained in camelina production and the total energy gain from camelina production (in a different study) was $59.2 \mathrm{GJ}^{-1}$ (Bielski et al., 2014). Meanwhile, much lower energy gains were obtained for camelina in the dryland farming system of central Montana: $14.9 \mathrm{GJ} \mathrm{ha}^{-1}$ (Keshavarz-Afshar et al., 2015) and $18.3 \mathrm{GJ} \mathrm{ha}^{-1}$

Table 5

Energy yield value and energy gain $\left(\mathrm{GJ} \mathrm{ha}^{-1}\right)$ of species depending on nitrogen fertilizer application in three successive experiment years.

\begin{tabular}{|c|c|c|c|c|c|c|c|c|}
\hline \multirow{3}{*}{$\begin{array}{l}\text { Year (nitrogen fertilizer rate }(\mathrm{kg} \\
\mathrm{ha}^{-1} \text { ) }\end{array}$} & \multicolumn{6}{|c|}{ Energy yield value } & \multicolumn{2}{|l|}{ Energy gain } \\
\hline & \multicolumn{2}{|l|}{ Seeds } & \multicolumn{2}{|l|}{ Straw } & \multicolumn{2}{|l|}{ Total } & \multicolumn{2}{|l|}{ Total } \\
\hline & Camelina & Crambe & Camelina & Crambe & Camelina & Crambe & Camelina & Crambe \\
\hline $2016(0)$ & $37.9 \pm 5.4$ & $43.9 \pm 10.2$ & $50.1 \pm 11.4$ & $43.1 \pm 16.7$ & $88.0 \pm 14.4$ & $86.9 \pm 26.7$ & $77.9 \pm 14.4$ & $76.8 \pm 26.7$ \\
\hline $2016(60)$ & $42.3 \pm 8.3$ & $45.3 \pm 1.9$ & $47.6 \pm 7.0$ & $44.1 \pm 5.7$ & $89.9 \pm 14.1$ & $89.4 \pm 6.3$ & $76.8 \pm 14.1$ & $76.1 \pm 6.3$ \\
\hline 2016 (120) & $42.9 \pm 6.5$ & $44.4 \pm 4.1$ & $38.3 \pm 7.7$ & $42.7 \pm 4.8$ & $81.1 \pm 14.0$ & $87.1 \pm 8.2$ & $64.9 \pm 14.0$ & $70.8 \pm 8.2$ \\
\hline $2017(0)$ & $28.5 \pm 6.3$ & $29.9 \pm 1.0$ & $23.9 \pm 7.6$ & $20.3 \pm 4.4$ & $52.3 \pm 7.1$ & $50.2 \pm 5.3$ & $42.2 \pm 7.1$ & $40.0 \pm 5.3$ \\
\hline $2017(60)$ & $34.2 \pm 4.0$ & $34.9 \pm 6.1$ & $23.7 \pm 5.5$ & $26.1 \pm 8.8$ & $58.0 \pm 9.3$ & $61.0 \pm 14.4$ & $44.8 \pm 9.3$ & $47.8 \pm 14.4$ \\
\hline 2017 (120) & $39.2 \pm 1.7$ & $33.0 \pm 6.4$ & $23.2 \pm 6.1$ & $23.8 \pm 4.1$ & $62.5 \pm 6.1$ & $56.8 \pm 8.9$ & $46.3 \pm 6.1$ & $40.5 \pm 8.9$ \\
\hline $2018(0)$ & $51.9 \pm 7.9$ & $75.3 \pm 7.6$ & $35.0 \pm 8.8$ & $60.9 \pm 25.4$ & $87.0 \pm 16.0$ & $136.2 \pm 32.6$ & $76.8 \pm 16.0$ & $126.0 \pm 32.6$ \\
\hline $2018(60)$ & $56.9 \pm 9.8$ & $69.1 \pm 2.4$ & $37.1 \pm 9.6$ & $43.6 \pm 3.2$ & $94.0 \pm 18.8$ & $112.7 \pm 5.2$ & $80.9 \pm 18.8$ & $99.5 \pm 5.2$ \\
\hline $2018(120)$ & $59.1 \pm 8.3$ & $73.3 \pm 3.3$ & $36.8 \pm 4.7$ & $48.3 \pm 5.5$ & $95.8 \pm 12.8$ & $121.6 \pm 3.3$ & $79.6 \pm 12.8$ & $105.3 \pm 3.3$ \\
\hline$(0)$ & $39.4 \pm 11.7 b$ & $49.7 \pm 20.9 a$ & $36.3 \pm 14.1$ & $41.4 \pm 23.6$ & $75.8 \pm 21.0 b$ & $91.1 \pm 43.0 a$ & $65.7 \pm 21.0$ & $80.9 \pm 43.0$ \\
\hline$(60)$ & $44.5 \pm 12.0 a b$ & $49.8 \pm 15.4 a$ & $36.1 \pm 12.3$ & $37.9 \pm 10.5$ & $80.6 \pm 21.4 a b$ & $87.7 \pm 23.7 a$ & $67.5 \pm 21.4$ & $74.5 \pm 23.7$ \\
\hline (120) & $47.1 \pm 10.6 a$ & $50.2 \pm 18.2 a$ & $32.8 \pm 9.1$ & $38.3 \pm 11.8$ & $79.8 \pm 17.7 a b$ & $88.5 \pm 28.4 a$ & $63.6 \pm 17.7$ & $72.2 \pm 28.4$ \\
\hline 2016 & $41.0 \pm 6.6 \mathrm{c}$ & $44.5 \pm 5.8 \mathrm{c}$ & $45.3 \pm 9.6 \mathrm{ab}$ & $43.3 \pm 9.6 \mathbf{a b}$ & $86.4 \pm 13.4 \mathrm{~b}$ & $87.8 \pm 15.0 \mathrm{~b}$ & $73.2 \pm 14.2 \mathbf{b}$ & $74.6 \pm 15.2 \mathbf{b}$ \\
\hline 2017 & $34.0 \pm 6.1 \mathrm{~d}$ & $32.6 \pm 5.1 \mathrm{~d}$ & $23.6 \pm 5.9 \mathrm{c}$ & $23.4 \pm 6.1 \mathrm{c}$ & $57.6 \pm 8.1 \mathrm{c}$ & $56.0 \pm 10.4 \mathrm{c}$ & $44.4 \pm 7.1 \mathrm{c}$ & $42.7 \pm 10.0 \mathrm{c}$ \\
\hline 2018 & $56.0 \pm 8.4 b$ & $72.6 \pm 5.3 \mathbf{a}$ & $36.3 \pm 7.3 \mathbf{b}$ & $50.9 \pm 15.7 \mathbf{a}$ & $92.3 \pm 15.1 \mathbf{b}$ & $123.5 \pm 20.1 \mathbf{a}$ & $79.1 \pm 14.7$ b & $110.2 \pm 21.0 \mathrm{a}$ \\
\hline Mean & $43.7 \pm 11.6 \mathrm{~b}$ & $49.9 \pm 17.8 \mathrm{a}$ & $35.1 \pm 11.8$ & $39.2 \pm 16.0$ & $78.7 \pm 19.6 \mathrm{~b}$ & $89.1 \pm 31.8 \mathrm{a}$ & $65.6 \pm 19.6 \mathrm{~b}$ & $75.8 \pm 32.0 \mathrm{a}$ \\
\hline
\end{tabular}

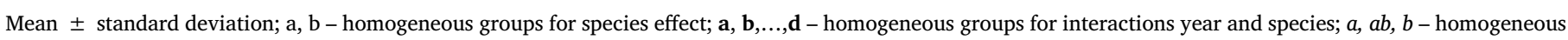
groups for interactions nitrogen fertilizer rate and species. No letter denotes statistical insignificance of the main effect or interaction. 


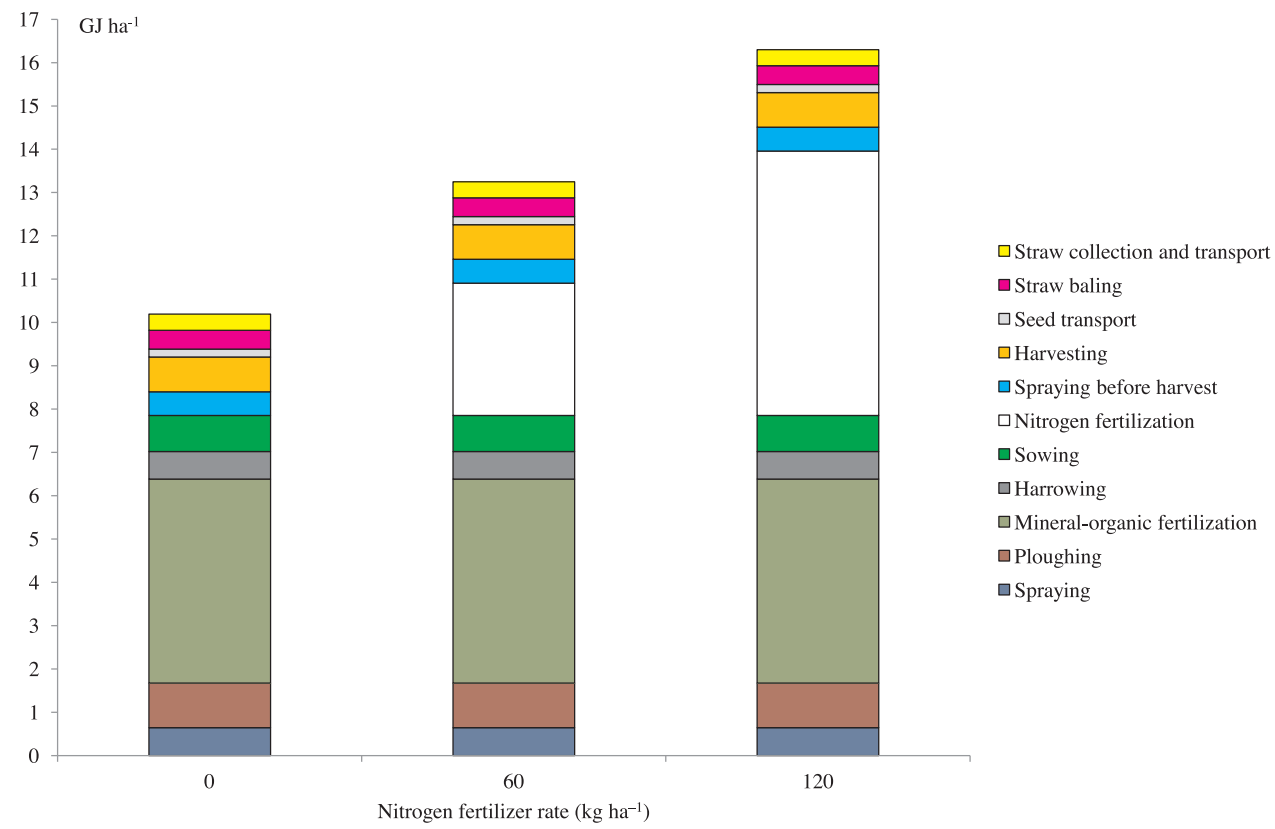

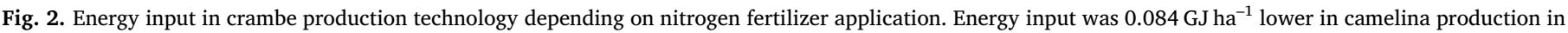
each production variant due to the lower weight of the sown seeds.

(Keshavarz-Afshar and Chen, 2015).

\subsection{Energy intensity}

The energy intensity to produce $1 \mathrm{Mg}$ of seed and straw was significantly differentiated only by $\mathrm{N}$ fertilization and experiment years. It was also differentiated by the interaction of the main oil production factors (Tables 2a and 2b). The average amount of energy consumed for the production of $1 \mathrm{Mg}$ of crambe seed $\left(7.0 \mathrm{GJ} \mathrm{Mg}^{-1}\right)$ was $9.8 \%$ lower compared to the average value for camelina (Table 6). The application of $\mathrm{N}$ fertilizer increased the energy intensity of seed production compared to the control plot with $0 \mathrm{~kg} \mathrm{ha}^{-1}$ artificial $\mathrm{N}$ applied, both for camelina and crambe (by $13-30 \%$, and by $22-55 \%$, respectively). An analysis of the results from the successive experiment years showed that the lowest $\left(3.2 \mathrm{GJ} \mathrm{Mg}^{-1}\right)$ and the highest $\left(12.1 \mathrm{GJ} \mathrm{Mg}^{-1}\right)$ values of this index were obtained in crambe production (in 2018 with no $\mathrm{N}$ fertilization and in 2017 with the highest $\mathrm{N}$ rate, respectively) and the energy intensity of camelina seed production ranged from 4.9 to $10.3 \mathrm{GJ} \mathrm{Mg}^{-1}$. The production energy intensity of $1 \mathrm{Mg}$ of camelina seeds in other studies was lower than in the current study. This index was two-fold lower in a variant with no $\mathrm{N}$ fertilization (only $2.7 \mathrm{GJ} \mathrm{Mg}^{-1}$ ) (KeshavarzAfshar et al., 2015). It increased to $6.3 \mathrm{GJ} \mathrm{Mg}^{-1}$ and $7.7 \mathrm{GJ} \mathrm{Mg}^{-1}$, when $\mathrm{N}$ fertilization was applied at 45 and $90 \mathrm{~kg} \mathrm{ha}^{-1}$, which was closer to the current results. Furthermore, the energy intensity for camelina seed production in a large-scale experiment was much higher $\left(12.0 \mathrm{GJ} \mathrm{Mg}^{-1}\right)$ and it was lower (by 0.8\%) compared to crambe (Stolarski et al., 2018). However, an analysis of the data obtained in successive years shows that the energy intensity was the lowest $\left(9.7 \mathrm{GJ} \mathrm{Mg}^{-1}\right)$ in crambe production in 2016. The energy intensity of oil crop seed production in Europe ranged from $4.8 \mathrm{GJ} \mathrm{Mg}^{-1}$ to $7.2 \mathrm{GJ} \mathrm{Mg}^{-1}$ for winter oilseed rape and white mustard (Jankowski et al., 2015; Budzyński et al., 2015; Stephenson et al., 2008) and 15.3-17.9 $\mathrm{GJ} \mathrm{Mg}^{-1}$ for spring oilseed rape and Indian mustard (Jankowski et al., 2015). The energy intensity of camelina and crambe seed production was thus lower than the production of spring rapeseed and Indian mustard seeds.

The energy intensity of straw production was much lower than in seed production (Table 6). The energy intensity of crambe straw production was $11 \%$ lower compared to camelina production. As with seeds, an increase in the $\mathrm{N}$ fertilization rate resulted in an increase in the energy intensity of straw production compared to the control plot with $0 \mathrm{~kg} \mathrm{ha}^{-1}$ artificial $\mathrm{N}$ applied, in both species. This index value ranged from $2.6 \mathrm{GJ} \mathrm{Mg}^{-1}$ to $10.6 \mathrm{GJ} \mathrm{Mg}^{-1}$ for crambe and from $3.2 \mathrm{GJ}$ $\mathrm{Mg}^{-1}$ to $11.0 \mathrm{GJ} \mathrm{Mg}{ }^{-1}$ for camelina throughout the experiment. The average energy intensity in the production of camelina straw in a largescale experiment was $3.6 \%$ lower compared to crambe production (Stolarski et al., 2018). In the study cited above, the index ranged from $5.3 \mathrm{Mg}^{-1}$ to $7.2 \mathrm{GJ} \mathrm{Mg}^{-1}$ for crambe and from $5.5 \mathrm{Mg}^{-1}$ to $6.4 \mathrm{GJ} \mathrm{Mg}^{-1}$ for camelina.

Much higher energy intensity was determined for oil in seeds. It was 21.5 GJ Mg ${ }^{-1}$ for camelina and higher (by nearly 12\%) for crambe (Table 6). Among the production technologies applied in the experiment, the lowest energy intensity for seed oil content was determined for camelina production with no $\mathrm{N}$ fertilization $\left(18.9 \mathrm{GJ} \mathrm{Mg}^{-1}\right)$. The application of $\mathrm{N}$ fertilization increased this index compared to the control plot with $0 \mathrm{~kg} \mathrm{ha}^{-1}$ artificial $\mathrm{N}$ applied, both for camelina and for crambe (by $11-30 \%$, and by $24-55 \%$, respectively). Moreover, a much higher energy intensity for seed oil content was determined in a large-scale experiment (Stolarski et al., 2018) compared to the average values in the current experiment $\left(32.7 \mathrm{GJ} \mathrm{Mg}^{-1}\right.$ for camelina and nearly $11 \%$ higher for crambe).

\subsection{Energy ratio}

The energy ratio for seed production and combined seed and straw production were significantly differentiated by the main factors and by the majority of interactions between them (Tables 2a and 2b). However, only $\mathrm{N}$ fertilizer application and the experiment years affected the energy ratio for straw.

The average energy ratio for crambe seed production (3.9) was significantly higher (by 13\%) compared to the average value for camelina (Table 7). The application of $\mathrm{N}$ fertilizer decreased the seed production energy ratio compared to the control plot with $0 \mathrm{~kg} \mathrm{ha}^{-1}$ artificial N applied, both for camelina and crambe (by $13-26 \%$, and by $23-37 \%$, respectively). The highest energy ratio in crambe and camelina seed production in the experiment was determined in 2018 for the variant with no $\mathrm{N}$ fertilization (7.4 and 5.1, respectively). The average energy ratio for straw production was lower compared to seeds (by $18 \%$ and $21 \%$, for camelina and crambe, respectively). 
a)

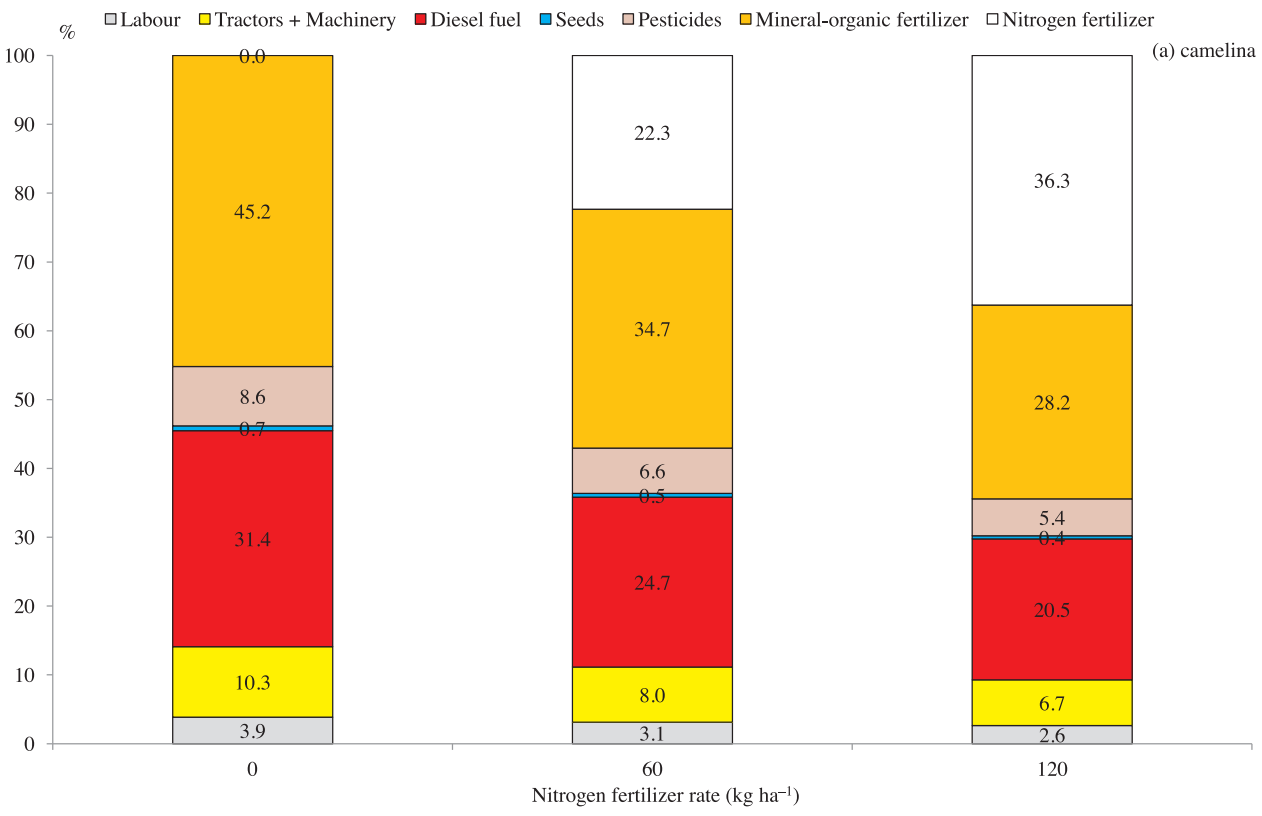

b)

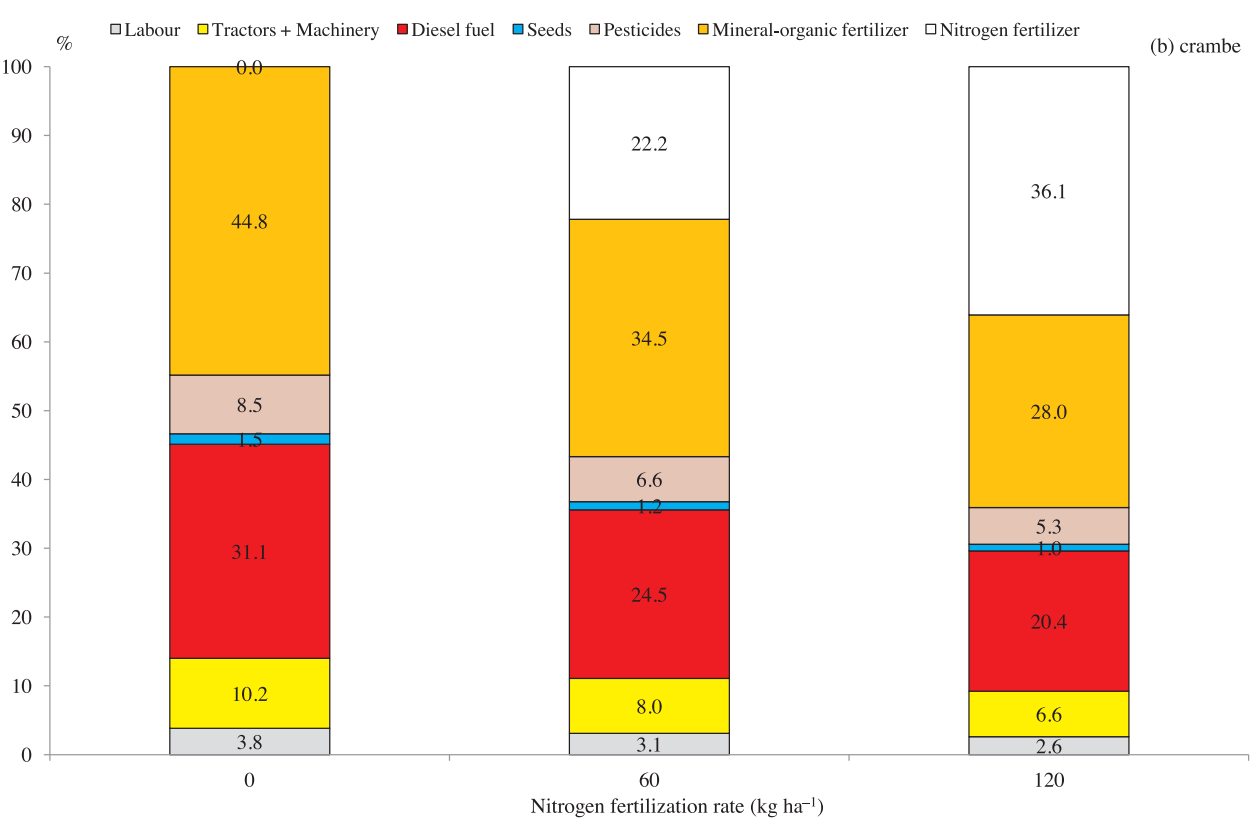

Fig. 3. Structure of energy input (\%) for (a) camelina and (b) crambe production in the energy stream, average for three years depending on nitrogen fertilizer application.

When the index for seeds and straw was taken into account, the average energy ratio for total biomass production of crambe (7.0) was $12 \%$ higher compared to the average value for camelina (Table 7 ). The application of $\mathrm{N}$ fertilizer significantly decreased this index compared to the plots with no fertilizer. The highest total energy ratio for biomass production was determined for crambe (13.4) in 2018. The index for crambe was $36-74 \%$ lower in the other years and for the other production variants. However, the highest total energy ratio for total camelina biomass production (8.7) was obtained in 2016 with no $\mathrm{N}$ fertilizer, and it was $1-56 \%$ lower in the other years and for the other production options. This demonstrates the greater stability and uniformity of camelina production compared to crambe.

A very high energy ratio in camelina seed production (10.4) was obtained in a different study for the option with no $\mathrm{N}$ fertilizer (Keshavarz-Afshar et al., 2015). This ratio decreased to 4.4 and 3.7 when the rate of $\mathrm{N}$ fertilizer application increased to 45 and $90 \mathrm{~kg} \mathrm{~N}$ $\mathrm{ha}^{-1}$, respectively, which was similar to the values obtained in this experiment. The average energy ratio for camelina seed production in another study in the dryland farming system of central Montana was 4.2. and it ranged from 2.0 to 5.5 in the study years (Keshavarz-Afshar and Chen, 2015). The energy ratio of camelina and crambe seed production in the current study was thus similar to the values cited above. A higher energy efficiency ratio for camelina seed production (4.6) was also demonstrated in other studies (Bielski et al., 2014). However, when analyzing the energy value of straw, it increased to 5.6, which was close to the average energy ratio for total camelina biomass determined in the current study. A lower energy ratio for seeds and straw production was obtained in a large-scale experiment (Stolarski et al., 2018). The average energy ratio for camelina seed production (2.0) was higher by $5.7 \%$ compared to the average value for crambe. The average energy 
Table 6

Energy intensity of seeds, straw and oil production ( $\mathrm{GJ} \mathrm{Mg}^{-1}$ ) for species depending on nitrogen fertilizer application in three successive study years.

\begin{tabular}{|c|c|c|c|c|c|c|c|c|c|}
\hline \multirow[t]{2}{*}{ Year (nitrogen fertilizer rate $\left(\mathrm{kg} \mathrm{ha}^{-1}\right)$} & \multicolumn{3}{|l|}{ Seeds } & \multicolumn{3}{|l|}{ Straw } & \multicolumn{3}{|l|}{ Oil } \\
\hline & Camelina & Crambe & Mean & Camelina & Crambe & Mean & Camelina & Crambe & Mean \\
\hline $2016(0)$ & $6.5 \pm 1.0$ & $5.5 \pm 1.3$ & $6.0 \pm 1.2$ & $3.2 \pm 0.6$ & $3.5 \pm 1.4$ & $3.4 \pm 1.1$ & $21.1 \pm 3.1$ & $18.4 \pm 4.4$ & $19.8 \pm 3.7$ \\
\hline $2016(60)$ & $7.6 \pm 1.6$ & $6.9 \pm 0.3$ & $7.3 \pm 1.2$ & $4.3 \pm 0.7$ & $4.5 \pm 0.6$ & $4.4 \pm 0.6$ & $23.0 \pm 4.7$ & $22.8 \pm 1.0$ & $22.9 \pm 3.2$ \\
\hline $2016(120)$ & $9.2 \pm 1.5$ & $8.6 \pm 0.8$ & $8.9 \pm 1.2$ & $6.5 \pm 1.3$ & $5.7 \pm 0.7$ & $6.1 \pm 1.1$ & $28.6 \pm 4.5$ & $28.3 \pm 2.7$ & $28.5 \pm 3.5$ \\
\hline $2017(0)$ & $8.9 \pm 2.1$ & $8.1 \pm 0.3$ & $8.5 \pm 1.5$ & $6.8 \pm 1.9$ & $7.8 \pm 2.1$ & $7.3 \pm 1.9$ & $22.8 \pm 5.3$ & $28.0 \pm 0.9$ & $25.4 \pm 4.2$ \\
\hline $2017(60)$ & $9.6 \pm 1.2$ & $9.1 \pm 1.5$ & $9.4 \pm 1.3$ & $8.8 \pm 2.2$ & $7.8 \pm 2.4$ & $8.3 \pm 2.1$ & $24.6 \pm 3.0$ & $32.4 \pm 5.4$ & $28.5 \pm 6.0$ \\
\hline 2017 (120) & $10.3 \pm 0.4$ & $12.1 \pm 2.2$ & $11.2 \pm 1.8$ & $11.0 \pm 2.4$ & $10.6 \pm 1.8$ & $10.8 \pm 2.0$ & $26.7 \pm 1.1$ & $42.0 \pm 7.8$ & $34.4 \pm 10.2$ \\
\hline $2018(0)$ & $4.9 \pm 0.8$ & $3.2 \pm 0.3$ & $4.1 \pm 1.1$ & $4.8 \pm 1.4$ & $2.6 \pm 1.5$ & $3.7 \pm 1.7$ & $12.8 \pm 2.0$ & $11.1 \pm 1.2$ & $12.0 \pm 1.8$ \\
\hline $2018(60)$ & $5.9 \pm 1.0$ & $4.5 \pm 0.2$ & $5.2 \pm 1.0$ & $5.9 \pm 1.7$ & $4.7 \pm 0.4$ & $5.3 \pm 1.4$ & $15.5 \pm 2.8$ & $16.0 \pm 0.6$ & $15.8 \pm 1.9$ \\
\hline $2018(120)$ & $7.0 \pm 1.0$ & $5.2 \pm 0.2$ & $6.1 \pm 1.2$ & $7.2 \pm 0.9$ & $5.3 \pm 0.7$ & $6.3 \pm 1.3$ & $18.4 \pm 2.7$ & $18.7 \pm 0.8$ & $18.6 \pm 1.8$ \\
\hline (0) & $6.8 \pm 2.2$ & $5.6 \pm 2.2$ & $6.2 \pm 2.3 C$ & $5.0 \pm 2.1$ & $4.6 \pm 2.8$ & $4.8 \pm 2.4 C$ & $18.9 \pm 5.9 c$ & $19.2 \pm 7.6 c$ & $19.1 \pm 6.6 C$ \\
\hline$(60)$ & $7.7 \pm 2.0$ & $6.8 \pm 2.2$ & $7.3 \pm 2.1 B$ & $6.3 \pm 2.5$ & $5.7 \pm 2.3$ & $6.0 \pm 2.4 B$ & $21.0 \pm 5.3 b c$ & $23.7 \pm 7.9 b$ & $22.4 \pm 6.7 B$ \\
\hline (120) & $8.8 \pm 1.7$ & $8.6 \pm 3.3$ & $8.7 \pm 2.6 A$ & $8.3 \pm 2.7$ & $7.2 \pm 2.8$ & $7.8 \pm 2.8 A$ & $24.6 \pm 5.4 b$ & $29.7 \pm 11.4 a$ & $27.2 \pm 9.1 A$ \\
\hline 2016 & $7.8 \pm 1.7$ & $7.0 \pm 1.5$ & $7.4 \pm 1.6 \mathrm{~B}$ & $4.7 \pm 1.7$ & $4.6 \pm 1.2$ & $4.7 \pm 1.4 \mathrm{~B}$ & $24.3 \pm 5.1 \mathrm{~b}$ & $23.1 \pm 4.8 \mathbf{b}$ & $23.7 \pm 4.9 \mathrm{~B}$ \\
\hline 2017 & $9.6 \pm 1.4$ & $9.7 \pm 2.4$ & $9.7 \pm 1.9 \mathrm{~A}$ & $8.9 \pm 2.7$ & $8.7 \pm 2.3$ & $8.8 \pm 2.4 \mathrm{~A}$ & $24.7 \pm 3.5 \mathrm{~b}$ & $34.1 \pm 8.2 \mathbf{a}$ & $29.4 \pm 7.9 \mathrm{~A}$ \\
\hline 2018 & $5.9 \pm 1.2$ & $4.3 \pm 0.9$ & $5.1 \pm 4.4 \mathrm{C}$ & $6.0 \pm 1.6$ & $4.2 \pm 1.4$ & $5.1 \pm 1.7 \mathrm{~B}$ & $15.6 \pm 3.3 \mathrm{c}$ & $15.3 \pm 3.4 \mathrm{c}$ & $15.5 \pm 3.3 \mathrm{C}$ \\
\hline Mean & $7.8 \pm 2.1$ & $7.0 \pm 2.8$ & & $6.5 \pm 2.8$ & $5.8 \pm 2.7$ & & $21.5 \pm 5.8$ & $24.2 \pm 9.9$ & \\
\hline
\end{tabular}

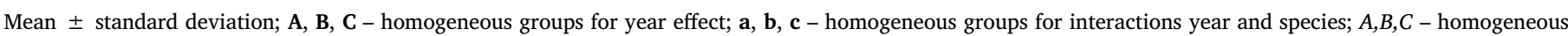

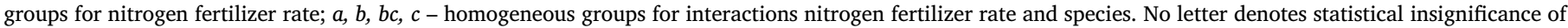
the main effect or interaction.

ratio for total camelina biomass production (4.8) was 4.2\% higher compared to the average value for crambe. The energy ratio in oil crop production (and for other species) varies and depends on many biological, site-related, technological, agrotechnical and material-related factors (Alluvione et al., 2011; Budzyński et al., 2015). The energy ratio in the production of various Brassicaceae species seeds ranged from 1.1 to 5.4 and it was much higher (from 9 to 12) when the energy value of straw was included (Bielski et al., 2014; Firrisa et al., 2014; Jankowski et al., 2015).

\section{Conclusions}

The yields of camelina and crambe biomass in the current study conducted in north-eastern Poland were not as high as in a warmer climate, e.g. in Mediterranean countries. However, camelina and crambe were found to give the highest yield in the warmest year 2018, when the rainfall amount was the lowest. Moreover, the current study has shown that camelina responded positively to a lower $\mathrm{N}$ rate with an increase in seed yield, whereas the crambe yield remained the same, regardless of the fertilization variant. The energy input was similar for the production of both species and increased with increasing $\mathrm{N}$ fertilization rates. However, the environmental factors mentioned above had a direct impact on the biomass yield energy value and energy efficiency indices, which were comparable to those obtained in the production of other oilseed spring species in the Polish climate zone.

The current study provides valuable information to farmers regarding the changing outlays and energy efficiency of camelina and crambe biomass production depending on the yield obtained in different years at a variable level of $\mathrm{N}$ fertilizer application. This information can be used in other regions to improve the energy balance of camelina and crambe biomass production. However, further research is needed to verify these findings and to improve production technology to reduce the energy input, which should contribute to an increase in the production energy efficiency of these species. Moreover, future studies will need to address the issue of economic and environmental production efficiency of these two promising spring oilseed crops.

Table 7

Energy ratio for seeds, straw and total biomass for species depending on nitrogen fertilizer application in three successive study years.

\begin{tabular}{|c|c|c|c|c|c|c|c|c|c|}
\hline \multirow{2}{*}{$\begin{array}{l}\text { Year (nitrogen fertilizer rate }(\mathrm{kg} \\
\mathrm{ha}^{-1} \text { ) }\end{array}$} & \multicolumn{3}{|l|}{ Seeds } & \multicolumn{3}{|l|}{ Straw } & \multicolumn{3}{|l|}{ Total } \\
\hline & Camelina & Crambe & Mean & Camelina & Crambe & Mean & Camelina & Crambe & Mean \\
\hline $2016(0)$ & $3.7 \pm 0.5$ & $4.3 \pm 1.0$ & $4.0 \pm 0.8 B C$ & $5.0 \pm 1.2$ & $4.2 \pm 1.6$ & $4.6 \pm 1.4$ & $8.7 \pm 1.4$ & $8.5 \pm 2.6$ & $8.6 \pm 2.0 \mathrm{~B}$ \\
\hline $2016(60)$ & $3.2 \pm 0.6$ & $3.4 \pm 0.1$ & $3.3 \pm 0.4 C$ & $3.6 \pm 0.5$ & $3.3 \pm 0.4$ & $3.5 \pm 0.5$ & $6.8 \pm 1.1$ & $6.7 \pm 0.5$ & $6.8 \pm 0.8 C$ \\
\hline 2016 (120) & $2.6 \pm 0.4$ & $2.7 \pm 0.2$ & $2.7 \pm 0.3 C D$ & $2.4 \pm 0.5$ & $2.6 \pm 0.3$ & $2.5 \pm 0.4$ & $5.0 \pm 0.9$ & $5.3 \pm 0.5$ & $5.2 \pm 0.7 C D$ \\
\hline $2017(0)$ & $2.8 \pm 0.6$ & $2.9 \pm 0.1$ & $2.9 \pm 0.4 C D$ & $2.4 \pm 0.8$ & $2.0 \pm 0.4$ & $2.2 \pm 0.6$ & $5.2 \pm 0.7$ & $4.9 \pm 0.5$ & $5.1 \pm 0.6 C D$ \\
\hline $2017(60)$ & $2.6 \pm 0.3$ & $2.6 \pm 0.5$ & $2.6 \pm 0.4 C D$ & $1.8 \pm 0.4$ & $2.0 \pm 0.7$ & $1.9 \pm 0.5$ & $4.4 \pm 0.7$ & $4.6 \pm 1.1$ & $4.5 \pm 0.9 D$ \\
\hline 2017 (120) & $2.4 \pm 0.1$ & $2.0 \pm 0.4$ & $2.2 \pm 0.3 D$ & $1.4 \pm 0.4$ & $1.5 \pm 0.3$ & $1.5 \pm 0.3$ & $3.9 \pm 0.4$ & $3.5 \pm 0.5$ & $3.7 \pm 0.5 \mathrm{D}$ \\
\hline $2018(0)$ & $5.1 \pm 0.8$ & $7.4 \pm 0.7$ & $6.3 \pm 1.4 \mathrm{~A}$ & $3.5 \pm 0.9$ & $6.0 \pm 2.5$ & $4.8 \pm 2.2$ & $8.6 \pm 1.6$ & $13.4 \pm 3.2$ & $11.0 \pm 3.5 \mathrm{~A}$ \\
\hline $2018(60)$ & $4.3 \pm 0.7$ & $5.2 \pm 0.2$ & $4.8 \pm 0.7 B$ & $2.8 \pm 0.7$ & $3.3 \pm 0.2$ & $3.1 \pm 0.6$ & $7.1 \pm 1.4$ & $8.5 \pm 0.4$ & $7.8 \pm 1.2 B$ \\
\hline 2018 (120) & $3.6 \pm 0.5$ & $4.5 \pm 0.2$ & $4.1 \pm 0.6 B C$ & $2.3 \pm 0.3$ & $3.0 \pm 0.3$ & $2.7 \pm 0.5$ & $5.9 \pm 0.8$ & $7.5 \pm 0.2$ & $6.7 \pm 1.0 \mathrm{C}$ \\
\hline$(0)$ & $3.9 \pm 1.2 b$ & $4.9 \pm 2.1 a$ & $4.4 \pm 1.7 A$ & $3.6 \pm 1.4$ & $4.1 \pm 2.3$ & $3.9 \pm 1.9 A$ & $7.5 \pm 2.1$ & $8.9 \pm 4.2$ & $8.2 \pm 3.3 A$ \\
\hline$(60)$ & $3.4 \pm 0.9 b c$ & $3.8 \pm 1.2 b$ & $3.6 \pm 1.0 \mathrm{~B}$ & $2.7 \pm 0.9$ & $2.9 \pm 0.8$ & $2.8 \pm 0.8 B$ & $6.1 \pm 1.6$ & $6.6 \pm 1.8$ & $6.4 \pm 1.7 B$ \\
\hline (120) & $2.9 \pm 0.7 c$ & $3.1 \pm 1.1 c$ & $3.0 \pm 0.9 C$ & $2.0 \pm 0.6$ & $2.3 \pm 0.7$ & $2.2 \pm 0.7 C$ & $4.9 \pm 1.1$ & $5.4 \pm 1.7$ & $5.2 \pm 1.4 C$ \\
\hline 2016 & $3.2 \pm 0.7 \mathrm{~cd}$ & $3.5 \pm 0.9 \mathrm{c}$ & $3.4 \pm 0.8 \mathrm{~B}$ & $3.6 \pm 1.3 \mathrm{ab}$ & $3.4 \pm 1.1 \mathrm{ab}$ & $3.5 \pm 1.2 \mathrm{~A}$ & $6.8 \pm 1.9 b$ & $6.9 \pm 2.0 \mathrm{~b}$ & $6.9 \pm 1.9 \mathrm{~B}$ \\
\hline 2017 & $2.6 \pm 0.4 \mathrm{~d}$ & $2.5 \pm 0.5 \mathrm{~d}$ & $2.6 \pm 0.8 \mathrm{C}$ & $1.9 \pm 0.6 \mathrm{c}$ & $1.8 \pm 0.5 \mathrm{c}$ & $1.9 \pm 0.6 \mathrm{~B}$ & $4.5 \pm 0.8 c$ & $4.3 \pm 0.9 \mathrm{c}$ & $4.4 \pm 0.9 \mathrm{C}$ \\
\hline 2018 & $4.4 \pm 0.9 \mathbf{b}$ & $5.7 \pm 1.3 \mathrm{a}$ & $5.1 \pm 1.3 \mathrm{~A}$ & $2.9 \pm 0.8 \mathbf{b}$ & $4.1 \pm 1.9 \mathbf{a}$ & $3.5 \pm 1.6 \mathrm{~A}$ & $7.2 \pm 1.7 \mathbf{b}$ & $9.8 \pm 3.2 \mathbf{a}$ & $8.5 \pm 2.8 \mathrm{~A}$ \\
\hline Species & $3.4 \pm 1.0 \mathrm{~b}$ & $3.9 \pm 1.6 \mathrm{a}$ & & $2.8 \pm 1.2$ & $3.1 \pm 1.6$ & & $6.2 \pm 1.9$ & $7.0 \pm 3.1$ & \\
\hline
\end{tabular}

Mean \pm standard deviation; $\mathrm{a}, \mathrm{b}-$ homogeneous groups for species effect; $\mathbf{A}, \mathbf{B}, \mathbf{C}-$ homogeneous groups for year effect; $\mathbf{a}, \mathbf{b}, \ldots, \mathbf{d}-$ homogeneous groups for interactions year and species $A, B, C$ - homogeneous groups for nitrogen fertilizer rate; $a, b, b c, c$ - homogeneous groups for interactions nitrogen fertilizer rate and species; $\boldsymbol{A}, \boldsymbol{B}, \ldots, \boldsymbol{D}$ - homogeneous groups for interactions year and nitrogen fertilizer rate. No letter denotes statistical insignificance of the main effect or interaction. 


\section{Acknowledgements}

This work was funded by European Union Horizon 2020 research and innovation programme under grant agreement No 635405 (project COSMOS). We would also like to thank the staff of the Department of Plant Breeding and Seed Production and Didactic and Research Station in Łężany for technical support during realization of the experiment.

\section{Appendix A. Supplementary data}

Supplementary material related to this article can be found, in the online version, at doi:https://doi.org/10.1016/j.indcrop.2019.05.047.

\section{References}

Alluvione, F., Moretti, B., Sacco, D., Grignani, C., 2011. EUE (energy use efficiency) of cropping systems for a sustainable agriculture. Energy 36, 4468-4481.

Berti, M., Gesch, R., Eynck, C., Anderson, J., Cermak, S., 2016. Camelina uses, genetics, genomics, production, and management. Ind. Crops Prod. 94, 690-710.

Berti, M., Wilckens, R., Fischer, S., Solis, A., Johnson, B., 2011. Seeding date influence on camelina seed yield, yield components, and oil content in Chile. Ind. Crops Prod. 34, 1358-1365.

Bielski, S., Jankowski, K., Budzyński, W., 2014. The energy efficiency of oil seed crops production and their biomass conversion into liquid fuels. Przem. Chem. 93, 2270-2273 (in Polish).

Budzyński, W.S., Jankowski, K.J., Jarocki, M., 2015. An analysis of the energy efficiency of winter rapeseed biomass under different farming technologies. A case study of a large-scale farm in Poland. Energy 90, 1272-1279.

Bustamante, D., Tortajada, M., Ramon, D., Rojas, A., 2019. Camelina oil as a promising substrate for mcl-PHA production in Pseudomonas sp. cultures. Appl. Food Biotechnol. 6, 61-70.

Falasca, S.L., Flores, N., Lamas, M.C., Carballo, S.M., Anschau, A., 2010. Crambe abyssinica: an almost unknown crop with a promissory future to produce biodiesel in Argentina. Int. J. Hydrogen Energy 35, 5808-5812.

Firrisa, M.T., Duren, I., Voino, V.A., 2014. Energy efficiency for rapeseed biodiesel production in different farming systems. Energy Effic. 7, 79-95.

Gesch, R., 2014. Influence of genotype and sowing date on camelina growth and yield in the north central U.S. Ind. Crops Prod. 54, 209-215.

Guan, R., 2014. Metabolic Engineering of Crambe abyssinica for Producing High Erucic Acid Oil. Doctoral Thesis. Swedish University of Agricultural Sciences, Alnarp pp. 49.

Jankowski, K., Budzyński, W., 2003. The role of yield components in the management of yielding of some spring oilseed crops. Rośliny Oleiste XXIV, 443-454 (in Polish).

Jankowski, K., Budzyński, W., 2004. Energetic potential of oil plants. Problemy Ekologii 2, 31-38 (in Polish).

Jankowski, K.J., Budzyński, W.S., Kijewski, Ł, 2015. An analysis of energy efficiency in the production of oilseed crops of the family Brassicaceae in Poland. Energy 81, 674-681.

Kalita, D.J., Tarnavchyk, I., Sibi, M., Moser, B.R., Webster, D.C., Chisholm, B.J., 2018. Biobased poly(vinyl ether)s derived from soybean oil, linseed oil, and camelina oil: synthesis, characterization, and properties of crosslinked networks and surface coatings. Prog. Org. Coat. 125, 453-462.

Keshavarz-Afshar, R., Chen, C., 2015. Intensification of dryland cropping systems for biofeedstock production: energy analysis of camelina. Bioenergy Res. 8, 1877-1884.

Keshavarz-Afshar, R., Mohammed, Y.A., Chen, Ch, 2015. Energy balance and greenhouse gas emissions of dryland camelina as influenced by tillage and nitrogen. Energy 91 , 1057-1063.

Khusainov, A.S., Glushchenko, A.A., Zartdinova, F.F., 2019. Application of bio-oil in hydraulic systems. In: Radionov, A., Kravchenko, O., Guzeev, V., Rozhdestvenskiy, Y. (Eds.), Proceedings of the 4th International Conference on Industrial Engineering. ICIE 2018. Lecture Notes in Mechanical Engineering. Springer, Cham.

Kulig, B., Szafrański, W., Kołodziej, J., 2004. Effect of weather conditions during vegetation period on yielding and canopy architecture of Crambe abissinica. Acta Agrophysica 3, 107-115 (in Polish).

Moser, B.R., 2010. Camelina (Camelina sativa L.) oil as a biofuels feedstock: golden opportunity or false hope? Lipid Technol. 22, 270-273.

Neeft, J., Gagnepain, B., Bacovsky, D., Lauranson, R., Georgakopoulos, K., Fehrenback, H., et al., 2011. Harmonized Calculations of Biofuel Greenhouse Gas Emissions in Europe, Netherlands. BioGrace standard values - version 4 - Public.xls. www. BioGrace.net.

Santos, J.I., Silva, T.R.B., Rogerio, F., Santos, R.F., Secco, D., 2013. Yield response in crambe to potassium fertilizer. Ind. Crops Prod. 43, 297-300.

Schillinger, W.F., Wysocki, D.J., Chastain, T.G., Guy, S.O., Karow, R.S., 2012. Camelina: planting date and method effects on stand establishment and seed yield. Field Crops Res. 130, 138-144.

Stephenson, A.L., Dennis, J.S., Scott, S.A., 2008. Improving the sustainability of the production of biodiesel from oilseed rape in the UK. Process Saf. Environ. Prot. 8, $427-440$.

Stolarski, M.J., Krzyżaniak, M., Kwiatkowski, J., Tworkowski, J., Szczukowski, S., 2018. Energy and economic efficiency of camelina and crambe biomass production on a large-scale farm in north-eastern Poland. Energy 150, 770-780.

Stolarski, M.J., Krzyżaniak, M., Śnieg, M., Christou, M., Alexopoulou, E., 2013. Production costs and residues evaluation of Crambe abyssinica as an energy feedstock. Environ Biotechnol. 9, 59-64.

Stolarski, M.J., Krzyżaniak, M., Tworkowski, J., Szczukowski, S., Niksa, D., 2016. Analysis of the energy efficiency of short rotation woody crops biomass as affected by different methods of soil enrichment. Energy 113, 748-761.

Stolarski, M.J., Krzyżaniak, M., Warmiński, K., Tworkowski, J., Szczukowski, S., Olba-Zięty, E., Gołaszewski, J., 2017. Energy efficiency of perennial herbaceous crops production depending on the type of digestate and mineral fertilizers. Energy 134, 50-60.

Szeptycki, A., Wójcicki, Z., 2003. Technical Development and Energy Inputs in Agriculture Till 2020. IBMER (in Polish), Warszawa.

Wang, Y.P., Tang, J.S., Chu, C.Q., Tian, J., 2010. A preliminary study on the introduction and cultivation of Crambe abyssinica in China, an oil plant for industrial uses. Ind. Crops Prod. 12, 47-52.

Zanetti, F., Eynck, Ch, Christou, M., Krzyżaniak, M., Righini, D., Alexopoulou, E., Stolarski, M.J., Van Loo, E.N., Puttick, D., Monti, A., 2017. Agronomic performance and seed quality attributes of camelina (Camelina sativa L. Crantz) in multi-environment trials across Europe and Canada. Ind. Crops Prod. 107, 602-608.

Zanetti, F., Monti, A., Berti, M.T., 2013. Challenges and opportunities for new industrial oilseed crops in EU-27: a review. Ind. Crops Prod. 50, 580-595.

Zanetti, F., Scordia, D., Vamerali, T., Copani, V., Dal Cortivo, C., Mosca, G., 2016. Crambe abyssinica a non-food crop with potential for the Mediterranean climate: insights on productive performances and root growth. Ind. Crops Prod. 90, 152-160. 